\title{
Cytotoxicity of anticancer aziridinyl-substituted benzoquinones in primary mice splenocytes
}

\author{
Valè Miliukienè, Henrikas Nivinskas and Narimantas Čènas ${ }^{\bowtie}$ \\ Institute of Biochemistry of Vilnius University, Vilnius, Lithuania
}

The anticancer activity of aziridinyl-quinones is mainly attributed to their $\mathrm{NAD}(\mathrm{P}) \mathrm{H}$ :quinone oxidoreductase 1 (NQO1)-catalyzed two-electron reduction into DNAalkylating products. However, little is known about their cytotoxicity in primary cells, which may be important in understanding their side effects. We found that the cytotoxicity of aziridinyl-unsubstituted quinones $(n=12)$ in mice splenocytes with a low amount of NQO1, $4 \mathrm{nmol} x$ $\mathrm{mg}^{-1} \times \mathrm{min}^{-1}$, was caused mainly by the oxidative stress. Aziridinyl-benzoquinones $(n=6)$ including a novel anticancer agent $\mathrm{RH} 1$ were more cytotoxic than aziridinylunsubstituted ones with the similar redox properties, and their cytotoxicity was not decreased by an inhibitor of NQ01, dicumarol. The possible reasons for their enhanced cytotoxicity are discussed.

Key words: aziridinyl-substituted quinones, cytotoxicity, oxidative stress

Received: 13 July, 2014; revised: 07 October, 2014; accepted: 12 November, 2014; available on-line: 18 December, 2014

\section{INTRODUCTION}

Aziridinyl-substituted benzoquinones (Fig. 1) comprise an important group of potential antitumour agents (DiFrancesco et al., 2004; Alcain \& Villalba, 2007; Parkinson et al., 2013, and references therein). Their antitumour activity stems mainly from the net two-electron reduction by flavoenzyme NAD $(\mathrm{P}) \mathrm{H}$ :quinone oxidoreductase (NQO1, EC 1.6.99.2) into corresponding hydroquinones, which alkylate DNA more rapidly than the parent quinones (Lee et al., 1992; DiFrancesco et al., 2004). It determines their enhanced cytotoxicity towards the cancer cell lines with high levels of NQO1 (Winski et al., 2001, and references therein). In parallel, they may exert the 'oxidative stress-type' cytotoxicity due to their reduction by NADPH: cytochrome P-450 reductase (P-450R, EC 1.6.2.4) or by other single-electron transferring flavoenzymes into their free radicals, which further undergo redox cycling (Hargreaves et al., 2000; Nemeikaitè-Č́niené<smiles>[R]C1=C(N2CC2)C(=O)C([R])=C(N2CC2)C1=O</smiles>

$$
\begin{aligned}
& \mathrm{R}_{1}=\mathrm{R}_{2}=-\mathrm{H}(\mathrm{DZQ}) \\
& \mathrm{R}_{1}=\mathrm{R}_{2}=-\mathrm{NHCOOC}_{2} \mathrm{H}_{5}(\mathrm{AZQ}) \\
& \mathrm{R}_{1}=\mathrm{R}_{2}=-\mathrm{CH}_{3}(\mathrm{MeDZQ}) \\
& \mathrm{R}_{1}=-\mathrm{CH}_{3}, \mathrm{R}_{2}=-\mathrm{CH}_{2} \mathrm{OH}(\mathrm{RH} 1) \\
& \mathrm{R}_{1}=\mathrm{R}_{2}=-\mathrm{NHC}_{2} \mathrm{H}_{4} \mathrm{OH}(\mathrm{BZQ})
\end{aligned}
$$

Figure 1. The formulae of diaziridinyl-benzoquinones used in this study. et al., 2003). Besides, the aziridinyl-substituted benzoquinones with strong electron-donating substituents, e.g., 2,5-bis(2'-hydroxyethylamino)-3,6-diaziridinyl-1,4-benzoquinone (BZQ, Fig. 1) may alkylate DNA directly, without bioreductive activation (Butler et al., 1990; Lee et al., 1992; Hargreaves et al., 2000).

On the other hand, certain aziridinyl-benzoquinones exert substantial side effects in vivo, e.g., lymphoid, bone marrow, and hematological toxicity (Hacker et al., 1982). It caused the withdrawal of trenimon (triaziridinyl-1,4benzoquinone) from the clinical use, and $\mathrm{AZQ}$ and $\mathrm{BZQ}$ (Fig. 1) from further clinical studies (Begleiter, 2000; Hargreaves et al., 2000). In our opinion, the cytotoxicity studies of aziridinyl-benzoquinones in primary (nontransformed) cell cultures may be helpful in understanding of the mechanisms of their side effects. However, their studies in primary cells are scarce, being mainly concentrated on the action of AZQ (O'Brien, 1991; Begleiter, 2000). In order to expand the knowledge in this field, we examined the cytotoxicity of two series of quinones, aziridinyl-substituted and -unsubstituted ones, in primary mice splenocytes. Our studies involved the new representative of aziridinyl-benzoquinones, RH1 (2,5-diaziridinyl-3-(hydroxymethyl)-6-methyl-1,4-benzoquinone; Fig. 1), which recently underwent preclinical and Phase-I clinical trials (Ward et al., 2005; Hussein et al., 2009; Danson et al., 2011).

\section{MATERIALS AND METHODS}

Enzymes and chemicals. Xanthine oxidase, xanthine, $\mathrm{H}_{2} \mathrm{O}_{2}, \mathrm{NADH}$, NADPH, cytochrome $c$, dicumarol, desferrioxamine, N,N'-diphenyl- $p$-phenylene diamine (DPPD), 1,3-bis(2-chloromethyl)-1-nitrosourea (BCNU), model quinones, glutathione (GSSG) were obtained from Sigma-Aldrich, and were used as received. Aziridinyl-substituted quinones (Fig. 1) were a generous gift from Dr. Jonas Šarlauskas (Institute of Biochemistry of Vilnius University). Their synthesis was performed according to the established methods (Cameron et al., 1968; Chou et al., 1976; Petersen et al., 1955; Winski et al., 1998). All the synthesized compounds

\footnotetext{
e-mail: narimantas.cenas@bchi.vu.lt

Abbreviations: AZQ, 2,5-bis(carboethoxy-amino)-3,6-diaziridinyl-1,4-benzoquinone; BCNU, 1,3-bis(2-chloromethyl)-1-nitrosourea; BZQ, 2,5-bis(2'-hydroxyethylamino)-3,6-diaziridinyl-1,4benzoquinone; $\mathrm{CL}_{50}$, the concentration of compound for $50 \%$ cell survival; DPPD, $N, N^{\prime}$-diphenyl-p-phenylene diamine; DZQ, 2,5-diaziridinyl-1,4-benzoquinone; $E^{1}$, redox potential of quinone/ semiquinone couple at $\mathrm{pH}$ 7.0; MeDZQ, 2,5-dimethyl-3,6-diaziridinyl-1,4-benzoquinone; NQO1, NAD(P)H:quinone oxidoreductase; $\mathrm{P}-450 \mathrm{R}, \mathrm{NADPH}$ :cytochrome $\mathrm{P}-450$ reductase; $\mathrm{RH} 1,2,5$-diaziridinyl3-(hydroxymethyl)-6-methyl-1,4-benzoquinone
} 
were characterized by a melting point and ${ }^{1} \mathrm{H}-\mathrm{NMR}$, UV, and IR spectroscopy.

Cell culture growth and cytotoxicity studies. In the studies of primary mice splenocytes, 4- to 8-week old male and female BALB $/ \mathrm{c}$ mice $(24 \pm 2.0 \mathrm{~g})$ were kept under standard conditions, and were given food and water ad libitum. The mice were sacrificed by decapitation, their spleen was removed according to an established procedure (Stack et al., 1999). These experiments were approved by the Lithuanian Veterinary and Food Service (License No. 0215, 2011). For each experiment, spleens of 3-5 mice were used as a source of splenocytes. Erythrocytes were lysed by $5 \mathrm{~min}$ exposure in lysis solution $\left(0.155 \mathrm{M} \mathrm{NH}_{4} \mathrm{Cl}, 10 \mathrm{mM} \mathrm{KCl}\right.$, $0.1 \mathrm{mM}$ EDTA). After washing the cells twice with RPMI 1640 medium, they were resuspended at the concentration of $10^{6}$ cells $/ \mathrm{ml}$ in RPMI 1640 medium with $5 \%$ fetal bovine serum and antibiotics, and were used for the further experiments. Cell viability was determined after $24 \mathrm{~h}$ of incubation of splenocytes with the examined compounds in 96-well cell culture plates (200 $\mu \mathrm{l}$ suspension per well), according to a Trypan blue exclusion test. The stock solutions of examined compounds were made in DMSO. The total concentration of DMSO in all the experiments was equal to $0.2 \%$, and did not affect the viability of the cells, 98$96 \%$, after their $24 \mathrm{~h}$ incubation.

Enzyme activity determination. Splenocytes were washed with PBS twice, and sonicated on ice in four cycles of $20 \mathrm{~s}$. The homogenate was centrifuged at $14000 \times g$ for $45 \mathrm{~min}$ and the resulting supernatant with added 1.0 mM PMSF was used for the further analysis. Protein amount was determined according to the method of Bradford. All the spectrometric measurements were performed using a Hitachi-557 spectrophotometer at $25^{\circ} \mathrm{C}$ in $0.1 \mathrm{M} \mathrm{K}$-phosphate $(\mathrm{pH}$ 7.0) containing $1 \mathrm{mM}$ EDTA. The activity of catalase was determined following the decomposition of 10 $\mathrm{mM} \mathrm{H} \mathrm{H}_{2} \mathrm{O}_{2}$ (Schallreuter et al., 1991). The activity of superoxide dismutase was determined from the inhibition of reduction of nitroblue tetrazolium by xanthine oxidase/xanthine system (Oberley \& Buettner, 1979). One unit of superoxide dismutase activity corresponds to an amount of protein needed to inhibit the reduction of nitroblue tetrazolium by $50 \%$. The activity of NAD(P)H:oxidase was determined according to the rate of oxidation of $100 \mu \mathrm{M} \operatorname{NAD}(\mathrm{P}) \mathrm{H}\left(\Delta \varepsilon_{340}=6.2\right.$ $\left.\mathrm{mM}^{-1} \mathrm{~cm}^{-1}\right)$. The activity of $\mathrm{NAD}(\mathrm{P}) \mathrm{H}$ :cytochrome $c$ reductase was determined according to the rate of reduction of $50 \mu \mathrm{M}$ cytochrome $c\left(\Delta \varepsilon_{550}=20 \mathrm{mM}^{-1} \mathrm{~cm}^{-1}\right)$ in the presence of $100 \mu \mathrm{M}$ NAD $(\mathrm{P}) \mathrm{H}$. The activity of glutathione reductase was determined according to the rate of oxidation of $100 \mu \mathrm{M}$ NADPH in the presence of $1.0 \mathrm{mM}$ GSSG. The activity of $\mathrm{NAD}(\mathrm{P}) \mathrm{H}$ :quinone oxidoreductase 1 (NQO1) was determined following the rate of reduction of $50 \mu \mathrm{M}$ cytochrome $c$ in the presence of $10 \mu \mathrm{M}$ menadione (2-methyl-1,4-naphthoquinone) and $100 \mu \mathrm{M}$ NADPH, as the difference between the reduction rate in the absence of dicumarol, and in its presence $(20 \mu \mathrm{M})$ (Lind et al., 1990). In this assay, Tween $20(0.01 \%)$ and bovine serum albu$\min \left(0.25 \mathrm{mg} \times \mathrm{ml}^{-1}\right)$ were used as the activators of NQO1.

Statistical analysis. Statistical data analysis was performed using Statistica (version 4.3, Statsoft Inc., 1993). Values are shown as standard error of mean. Where appropriate, the data were analyzed using a Student's $t$-test.

\section{RESULTS}

First, we determined the activities of redox enzymes which may be important in quinone cytotoxicity in splenocytes. The activity of NQO1 was relatively low, being equal to $4.0 \pm 0.3 \mathrm{nmol} \times \mathrm{mg}^{-1} \times \mathrm{min}^{-1}$. The activities of the prooxidant enzymes NADH:oxidase, NADPH:oxidase, NADH: cytochrome $c$ reductase, and NADPH:cytochrome $c$ reductase (P-450R), were equal to $2.9 \pm 0.3$ $\mathrm{nmol} \times \mathrm{mg}^{-1} \times \mathrm{min}^{-1}, 4.2 \pm 0.3 \mathrm{nmol} \times \mathrm{mg}^{-1} \times \mathrm{min}^{-1}$, $7.2 \pm 0.5 \mathrm{nmol} \times \mathrm{mg}^{-1} \times \mathrm{min}^{-1}$, and $11.1 \pm 1.0 \mathrm{nmol} \times$ $\mathrm{mg}^{-1} \times \mathrm{min}^{-1}$, respectively. The activities of the antioxidant enzymes glutathione reductase, catalase, and superoxide dismutase were equal to $4.3 \pm 0.5 \mathrm{nmol} \times \mathrm{mg}^{-1}$ $\times \min ^{-1}, 43.7 \pm 3.0 \mu \mathrm{mol} \times \mathrm{mg}^{-1} \times \mathrm{min}^{-1}$, and $1.0 \pm 0.2$ units $/ \mathrm{mg}$, respectively.

Next, we examined the 24-h cytotoxicity of model aziridinyl-unsubstituted quinones $(n=12)$ in splenocytes. The data of Table 1 show that their concentrations for $50 \%$ cell survival $\left(\mathrm{cL}_{50}\right)$ decreased with an increase in their single-electron reduction potential $\left(E_{7}^{1}\right)$, and ranged from 4.0 $\pm 0.4 \mu \mathrm{M}$ (5-hydroxy-1,4-naphthoquinone, $E_{7}^{1}$ $=-0.09 \mathrm{~V}$ ) to $1000 \pm 100 \mu \mathrm{M}$ (2-hydroxy-1,4-naphthoquinone, $E_{7}^{1}=-0.41 \mathrm{~V}$ ). The dependence of $\log \mathrm{cL}_{50}$ on $E_{7}^{1}$ of quinones is parabolic (Fig. 2), being in line with the previously observed parabolic or linear $\log \mathrm{cL}_{50}$ vs. $E_{7}^{1}$ relationships with $\Delta \log \mathrm{cL}_{50} / \Delta E_{7}^{1} \sim-10 \mathrm{~V}^{-1}$ in their aerobic cytotoxicity in several mammalian cell lines (Nemeikaite-C̈enienè et al., 2003, and references therein). It points to the dominating role of their oxidative stress-type cytotoxicity. It reflects the ease of the singleelectron reduction of quinones by P-450R or by similar single-electron transferring flavoenzymes, which initiate their redox cycling. The reaching of the limiting value of $\mathrm{cL}_{50}$ of quinones at high redox potentials may be explained by the instability of high potential partly-substituted quinones, i.e., their rapid trapping by reduced

Table 1. Redox potentials of quinone/semiquinone couples of quinones at pH $7.0\left(E^{1}\right)$ (Wardman, 1989; Čènas et al., 2004, and references therein), and their concentrations for $50 \%$ survival of primary mice splenocytes during $24 \mathrm{~h}$ incubation $\left(\mathrm{cL}_{50}\right)$.

\begin{tabular}{l|cc}
\hline No. Compound & $E_{7}^{1}(\mathrm{~V})$ & $\mathrm{CL}_{50}(\mu \mathrm{M})$ \\
\hline 1. 2-Methyl-1,4-benzoquinone & 0.01 & $6.3 \pm 0.4$ \\
\hline 2. 2,3-Dichloro-1,4-naphthoquinone & -0.035 & $13.0 \pm 1.9$ \\
\hline 3. DZQ & -0.054 & $6.3 \pm 0.7$ \\
\hline 4. AZQ & -0.07 & $3.0 \pm 0.4$ \\
\hline 5. 5,6-Dimethyl-1,4-benzoquinone & -0.08 & $5.0 \pm 0.4$ \\
\hline 6. 5-Hydroxy-1,4-naphthoquinone & -0.09 & $4.0 \pm 0.4$ \\
\hline 7. 5,8-Dihydroxy-1,4-naphthoquinone & -0.11 & $6.0 \pm 0.5$ \\
\hline 8. 9,10-Phenanthrene quinone & -0.12 & $6.3 \pm 0.6$ \\
\hline 9. 1,4-Naphthoquinone & -0.15 & $11.5 \pm 1.9$ \\
\hline 10. 2-Methyl-1,4-naphthoquinone & -0.20 & $14.0 \pm 1.0$ \\
\hline 11. MeDZQ & -0.23 & $5.5 \pm 0.4$ \\
\hline 12. RH1 & -0.23 & $4.2 \pm 0.5$ \\
\hline 13. Trimethyl-aziridinyl-1,4-benzoquinone & -0.23 & $2.9 \pm 0.4$ \\
\hline 14. Tetramethyl-1,4-benzoquinone & -0.26 & $32.0 \pm 4.0$ \\
\hline 15. 1,4-Dihydroxy-9,10-anthraquinone & -0.30 & $106 \pm 12$ \\
\hline 16. 1,8-Dihydroxy-9,10-anthraquinone & -0.33 & $\geq 250$ \\
\hline 17. BZQ & -0.38 & $9.8 \pm 0.8$ \\
\hline 18. 2-Hydroxy-1,4-naphthoquinone & -0.41 & $1000 \pm 100$ \\
\hline
\end{tabular}




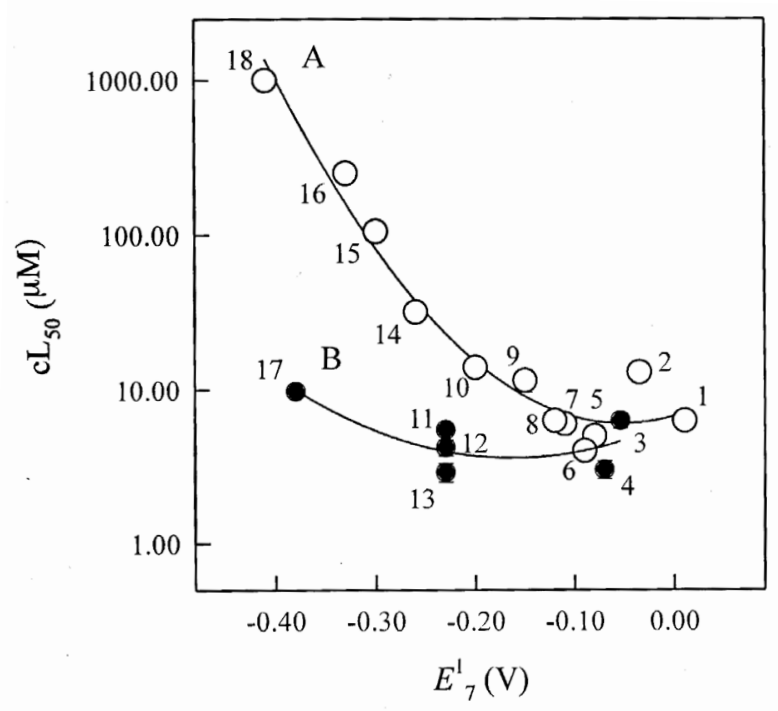

Figure 2. The dependence of the cytotoxicity of aziridinyl-unsubstituted and -substituted quinones in primary splenocytes on their single-electron reduction potential $\left(E^{1}{ }_{7}\right)$.

The dependences of the concentrations of aziridinyl-unsubstituted (A) and -substituted (B) quinones causing the $50 \%$ survival of the cells $\left(\mathrm{CL}_{50}\right)$ are presented as the second order approximations, the numbers of quinones are taken from Table 1.

glutathione (GSH) and other cellular nucleophiles, and/ or their impaired redox cycling ability (Wardman et al., 1995).

Importantly, aziridinyl-substituted quinones RH1, MeDZQ, trimethyl-2-aziridinyl-1,4-benzoquinone, and, especially, BZQ (Fig. 1) exhibited higher cytotoxicity than it may be expected from their $E^{1}$ value (Fig. 2). It points to the additional mechanisms of their action.

Further, we found that the cytotoxicity of RH1 at close to $\mathrm{cL}_{50}$ concentration was partly protected by the antioxidant $N, N^{\prime}$-diphenyl- $p$-phenylene diamine (DPPD), the iron ion chelator desferrioxamine, and potentiated by the prooxidant BCNU, the latter inactivating the antioxidant enzyme glutathione reductase, and depleting GSH

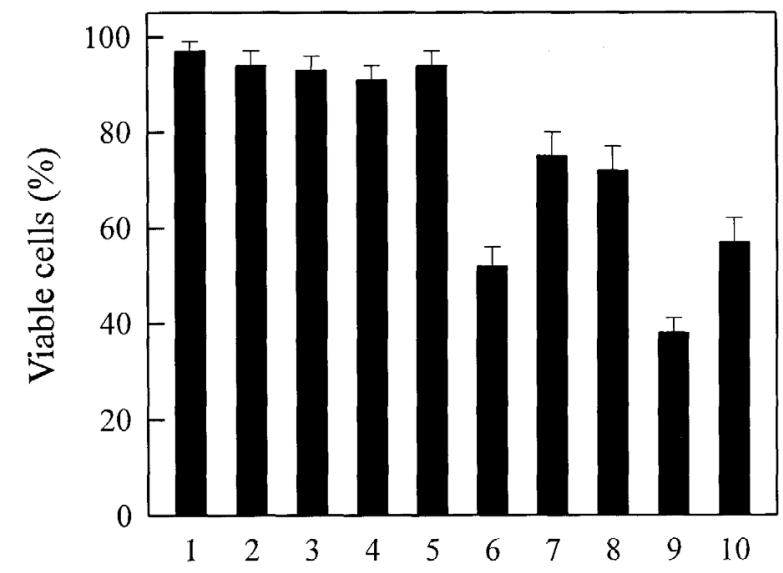

Figure 3. The modulation of the cytotoxicity of RH1.

Viability of control splenocytes (1-5), additions - none (1), 3.0 $\mu \mathrm{M}$ DPPD (2), $300 \mu \mathrm{M}$ desferrioxamine (3), $20 \mu \mathrm{M}$ BCNU (4), $20 \mu \mathrm{M}$ dicumarol (5), 4.0 $\mu \mathrm{M}$ RH1 (6), 4.0 $\mu \mathrm{M} \mathrm{RH1} \mathrm{+} \mathrm{3.0} \mathrm{\mu M} \mathrm{DPPD} \mathrm{(7),} 4.0$ $\mu \mathrm{M} \mathrm{RH} 1+300 \mu \mathrm{M}$ desferrioxamine (8), $4.0 \mu \mathrm{M} \mathrm{RH} 1+20 \mu \mathrm{M}$ BCNU (9), and 4.0 $\mu \mathrm{M} \mathrm{RH} 1+20 \mu \mathrm{M}$ dicumarol (10), $n=3, P>0.2$ for $2-5$ against $1, P<0.002$ for 7,8 against $6, P<0.02$ for 9 against 6 , and $P>0.05$ for 10 against 6 .
(Öllinger \& Brunmark, 1991) (Fig. 3). Importantly, the cytotoxicity of RH1 was not protected by an inhibitor of NQO1, dicumarol (Fig. 3). Analogous protection/potentiation effects by DPPD, desferrioxamine, and BCNU were observed in the cytotoxicity of tetramethyl-1,4-benzoquinone (duroquinone) and BZQ (data not shown). Duroquinone is a nonalkylating analogue of RH1 with similar reactivity towards the single-electron transferring $\mathrm{P}-450 \mathrm{R}$ and two-electron transferring NQO1 (Nemeikaitè-Čenienè et al., 2003). On the other hand, BZQ undergoes redox cycling and directly alkylates DNA, but is not a substrate for NQO1 (DiFrancesco et al., 2004). Analogously, dicumarol also did not protect against the cytotoxicity of duroquinone and BZQ (data not shown).

\section{DISCUSSION}

According to our best knowledge, the previous primary cell cytotoxicity studies of aziridinyl-benzoquinones were scarce, and did not disclose their specific mode(s) of action. They involved the short-time testing of AZQ in rat hepatocytes (O'Brien, 1991), a study of trenimon derivatives in primary human skin fibroblasts (Huang et al., 2009), and the related genotoxic studies of AZQ in lymphocytes (Klingerman et al., 1988), as well as the cytotoxicity of AZQ and DZQ in mice epidermal cells ( $\mathrm{Li}$ et al., 1999). In contrast, our data provide a more quantitative insight into the cytotoxicity of aziridinyl-substituted quinones in primary cells with a low amount of NQO1. In our opinion, the primary splenocytes used in this study, are a more advantageous model as compared to primary hepatocytes, because of the possibility to perform longer 24-h cytotoxicity tests.

Previously, we found that the cytotoxicity of aziridinyl-benzoquinones in transformed cells with high activity of NQO1, $250 \mathrm{nmol} \times \mathrm{mg}^{-1} \times \mathrm{min}^{-1}$, was 10 100 times higher than that of aziridinyl-unsubstituted quinones possessing the same $E^{1}$ values (NemeikaiteCeniene et al., 2003). The current data show that in spite of the low activity of NQO1 in splenocytes, $4.0 \mathrm{nmol}$ $\times \mathrm{mg}^{-1} \times \mathrm{min}^{-1}$, the cytotoxicity of aziridinyl-benzoquinones is still enhanced (Fig. 2). The much enhanced cytotoxicity of BZQ (Fig. 2) may be explained by its direct alkylation of DNA without the involvement of enzymatic activation (Butler et al., 1990). In contrast, MeDZQ and RH1 do not alkylate DNA directly (Lee et al., 1992; DiFrancesco et al., 2004), but they still possess increased cytotoxicity, which, in the case of RH1, is not related to the action of NQO1, because it is not inhibited by dicumarol (Fig. 3). The protective effects of DPPD and desferrioxamine against the action of RH1 (Fig. 3) indicate that its cytotoxicity is partly attributed to the oxidative stress. However, in our opinion, the higher cytotoxicity of RH1, MeDZQ and aziridinyl-benzoquinones with the higher values of $E^{1}{ }_{7}$ (Table 1, Fig. 2) may not be attributed to their enhanced redox cycling, because both aziridinyl-substituted and -unsubstituted quinones follow the same $\log$ (rate constant) vs. $E^{1}$ relationship in their P-450R-catalyzed single-electron reduction (Nemeikaité-Čnienè et al., 2003). On the other hand, it may be caused by other currently insufficiently addressed NQO1-independent cytotoxicity modes (Tudor et al., 2005), e.g., a net two-electron reduction of aziridinyl-benzoquinones by single-electron transferring enzymes into their DNA-alkylating hydroquinones under partly anaerobic conditions (Anusevičius et al., 2013), which may take place in relatively anaerobic cell compartments, or, possibly, the action of dihydronicotinamide riboside:qui- 
none oxidoreductase 2 (NQO2) (Yan et al., 2008). These problems warrant a more thorough examination. However, the enhanced cytotoxicity of RH1 in splenocytes (Fig. 2) is in line with its significant suppressive effects on the cells of the immune system, which were observed during its Phase-I clinical trials (Danson et al., 2011). It shows that this novel compound may be not devoid of significant side effects even in the cells with low content of NQO1, which may limit its further clinical application.

\section{Acknowledgements}

This research was funded by the European Social fund under the Global Grant Measure No. VP1-3.1ŠMM-07-K01-103 (Scientific Council of Lithuania).

\section{REFERENCES}

Alcain FJ, Villalba JM (2007) NQO1-directed antitumour quinones. Expert Opin Ther Pat 17: 649-665.

Anusevičius Ž, Nivinskas H, Šarlauskas J, Sari MA, Boucher J-L, Čènas N (2013) Single-electron reduction of quinone- and nitroaromatic xenobiotics by recombinant rat neuronal nitric oxide synthase. Acta Biochim Pol 60: 217-222.

Begleiter A (2000) Clinical applications of quinone-containing alkylating agents. Frontiers Biosci 5: e153-e171.

Butler J, Dzieliendziak A, Lea JS, Ward TH, Hoey BM (1990) Contrasting cytotoxic mechanisms of similar antitumour diaziridinyl-benzoquinones. Free Rad Res Commun 8: 231-239.

Cameron DW, Gilles RGF, (1968) Photochemical formation of benzoxalizone derivatives from aminated quinones. J Chem Soc C 14611464.

Čènas N, Anusevičius Ž, Nivinskas H, Misevičiené L, Šarlauskas J (2004) Structure-activity relationships in two-electron reduction of quinones. Methods Enyymol 382B: 258-277.

Chou F, Chan AH, Driscoll JS (1976) Potential central nervous system antitumour agents. Aziridinylbenzoquinones. J Med Chem 28: 1302-1308.

Danson SJ, Johnson P, Ward TH, Dawson M, Denneny O, Dickinson G, Aarons L, Watson A, Jowle D, Cummings J, Robson L, Halbert G, Dive C, Ranson M (2011) Phase I pharmacokinetic and pharmacodynamic study of the bioreductive drug RH1. Ann Oncol 22: 1853-1860.

DiFrancesco A, Ward TH, Butler J (2004) Diaziridinylbenzoquinones. Methods Enzymol 382B: 174-193.

Hacker MP, Hong CB, McKee MJ, Unwin SE, Urbanek SA (1982) Toxicity of aziridinyl benzo quinone administrated intra venously to beagle dogs. Cancer Treat Rep 66: 1845-1852.

Hargreaves RHJ, Hartley JA, Butler J (2000) Mechanisms of action of quinone-containing alkylating agents: DNA alkylation by aziridinylquinones. Frontiers Biosci 5: e172-e180.

Huang CH, Kuo H-S, Liu J-W, Lin Y-L (2009) Synthesis and antitumour evaluation of novel bis-triaziquone derivatives. Molecules 14: 2306-2316.

Hussein D, Holt SV, Brookes KE, Klymenko T, Adamski JK, Hogg A, Estlin EJ, Ward T, Dive C (2009) Preclinical efficacy of the bioreductive alkylating agent $\mathrm{RH} 1$ against paediatric tumours. $\mathrm{Br} J$ Cancer 101: 55-63.

Klingerman AD, Erexson GL, Bryant MF (1988) Sister chromatid exchange induction by diaziquone in human and mouse lymphocytes following both in vivo and in vitro exposures. Cancer Res 48: 27-31.
Lee C-S, Hartley JA, Berardini MD, Butler J, Siegel D, Ross D, Gibson NW (1992) Alteration in DNA cross-linking and sequence selectivity of a series of aziridinylbenzoquinones after enzymatic reduction by DT-diaphorase. Biochemistry 31: 3019-3025.

Li B, Guttierrez PL, Amstad P, Blough NV (1999) Hydroxyl radical production by mouse epidermal cell lines in the presence of quinone anti-cancer compounds. Chem Res Toxicol 12: 1042-1049.

Lind C, Cadenas E, Hochstein P, Ernster L (1990) DT-diaphorase: purification, properties, and function. Methods Ensymol 186: 287-301.

Nemeikaite-Cénienė A, Šarlauskas J, Anusevičius Ž, Nivinskas H, Čènas N (2003) Cytotoxicity of RH1 and related aziridinylbenzoquinones: involvement of activation by $\mathrm{NAD}(\mathrm{P}) \mathrm{H}$ :quinone oxidoreductase (NQO1) and oxidative stress. Arch Biochem Biophys 416: 110-118.

Oberley LW, Buettner GR (1979) Role of superoxide dismutase in cancer: a review. Cancer Res 39: 1141-1149.

O'Brien PJ (1991) Molecular mechanisms of quinone cytotoxicity. Chem-Biol Interact 80: 1-41.

Öllinger K, Brunmark A (1991) Effect of hydroxyl substituent position on 1,4-naphthoquinone toxicity to rat hepatocytes. J Biol Chem 266: 21496-21503.

Parkinson EI, Bair JS, Cismesia M, Hergenrother PJ (2013) Efficient NQO1 substrates are potent and selective anticancer agents. ACS Chem Biol 8: 2173-2183.

Petersen S, Gauss W, Urbschat E (1955) Synthese einfacher chinonderivation mit fungiziden, bakteriostatischen oder cytostatischen eigenschaften. Angew Chem 67: 1461-1464.

Schallreuter KU, Wood JK, Berger J (1991) Low catalase levels in the epidermis of patients with vitiligo. J Invest Dermacol 97: 1081-1085.

Stack AS, Altman-Hamamdzic S, Morris PJ, London SD, London L (1999) Polychlorinated biphenyl mixtures (Aroclors) inhibit LPSinduced murine splenocyte proliferation in vitro. Toxicology 139: 137154.

Tudor G, Alley M, Nelson CM, Huang R, Covell D, Gutierrez P, Sausville EA (2005) Cytotoxicity of RH1: NAD(P)H:quinone acceptor oxidoreductase (NQO1)-independent oxidative stress and apoptosis induction. Anti-Cancer Drugs 16: 381-391.

Ward TH, Danson S, McGown AT, Ranson M, Coe NA, Jayson GC, Hargreaves RHJ, Butler J (2005) Preclinical evaluation of the pharmacodynamic properties of 2,3-diaziridinyl-3-hydroxymethyl-6-methyl-1,4-benzoquinone. Clin Canc Res 11: 2695-2701.

Wardman P (1989) Reduction potentials of one-electron couples involving their radicals in aqueous solutions. I Phys Chem Ref Data 18: 1637-1755.

Wardman P, Dennis MF, Everet SA, Patel KB, Stratford MR, Tracy M (1995) Radicals from one-electron reduction of nitro compounds, aromatic $N$-oxides and quinones: the kinetic basisfor hypoxia-selective bioreductive drugs. Biochem Soc Symp 61: 171-194.

Winski SL, Hargreaves RHJ, Butler J, Ross D (1998) A new screening system for $\mathrm{NAD}(\mathrm{P}) \mathrm{H}$ :quinone oxidoreductase (NQO1)-directed antitumour quinones: Identification of a new aziridinylbenzoquinone RH1, an NQO1-directed antitumour agent. Clin Cancer Res 4: 3083-3088.

Winski SL, Swann E, Hargreaves RHJ, Dehn DL, Butler J, Moody CJ, Ross D (2001) Relationship between NAD $(\mathrm{P}) \mathrm{H}$ :quinone oxidoreductase 1 (NQO1) levels in a series of stably transfected cell lines and susceptibility to antitumor quinones. Biochem Pharmacol 61: 1509-1516.

Yan C, Kepa JK, Siegel D, Stratford IJ, Ross D (2008) Dissecting the role of multiple reductases in bioactivation and cytotoxicity of the antitumour agent 2,5-diaziridinyl-3-(hydroxymethyl)-6-methyl-1,4-benzoquinone (RH1). Mol Pharmacol 74: 1657-1665. 